\title{
AT THE BORDERS-THE NEW HORIZONS OF WATER MANAGEMENT AND WATER LAW
}

\begin{abstract}
Mark S. Davis*
"Water, like religion and ideology, has the power to move millions of people. Since the very birth of human civilization, people have moved to settle close to it. People move when there is too little of it. People move when there is too much of it. People journey down it. People write, sing and dance about it. People fight over it. And all people, everywhere and every day, need it."- Mikhail Gorbachev.
\end{abstract}

\section{INTRODUCTION}

Water and boundaries are old friends. Rivers and lakes often mark the limits of nations, states, and cities. Shores and coastlines can mark the limits between public and private rights. Maps and surveys have memorialized these two-dimensional boundaries with lines that tell us what is mine, what is yours, and which sovereign writes the rules. It all seems so simple, so natural and straight forward.

But unlike our affinity for clarity and constancy, water revels in change, and as it changes so do our relations with it. Nowhere is the challenge of managing water more fraught than at the borders where the friction from competing interests, conflicting legal regimes, and politics sometimes gets heated to the point of flame.

Transboundary water discussions often focus on disputes between nations over water resources. Those are complex enough, but within federal forms of government, such as ours, there is also a robust history of conflicts among states ${ }^{2}$ and between states and the federal government. ${ }^{3}$ But to confine the notion of transboundary water management to political boundaries would be a mistake. To understand, prepare for, and respond to the water challenges posed by growing demand, shifting supplies, and climate change we are going to have to expand our understanding of borders to include a wider view of boundaries, a view that would include, at

* Senior Research Fellow, Tulane Law School and Director of the Tulane Institute on Water Resources Law and Policy.

1. Mikhail Gorbachev, Foreword to Peter Swanson, Water: The Drop of LIFe 7 (2001).

2. See, e.g., Ariz. v. Cal., 373 U.S. 546 (1963); Tex. v. N.M., 462 U.S. 554 (1983); Conn. v. Mass., 282 U.S. 660 (1931); Tarrant v. Herrmann, 133 S.Ct. 2120 (2013).

3. See, e.g., United States v. Cal., 332 U.S. 19, 38-39 (1947); United States v. La., 339 U.S. 699 (1950). 
the least:

1. National boundaries;

2. Internal geopolitical boundaries;

3. Physical boundaries;

4. Hydrologic boundaries;

5. Ecologic boundaries;

6. Legal boundaries;

7. Cultural boundaries;

8. Economic boundaries;

9. Professional boundaries;

10. Boundaries between what we know and don't know; and

11. Boundaries between our "unshakable" beliefs and those beliefs we are willing to challenge.

While this list, which will be revisited later, may appear daunting, even confounding, it in fact paints a fair picture of the issues and challenges facing those working to develop more comprehensive and dynamic approaches to water management. ${ }^{4}$ The intractable pace and disappointing results of many of those efforts is in large part a function of the fact that our current approaches to planning for and managing water are ill equipped to even acknowledge that all of those boundaries exist, much less deal with them.

Water and law are not natural fits. Water is dynamic, shaping and lifegiving. Water law is basically about continuity, predictability, and controlling freshwater so it can be used to some property owner's or community's advantage. Water naturally ignores definitional distinctions between flowing waters, navigable waters, groundwater, coastal waters and seas. But water law traditionally is very much about those things. Driven by scarcity and the growing awareness of the connections between the sustainability of ecosystems and human societies, water management is being driven to a more comprehensive style of management. Water law and policy are being dragged along, watershed by watershed, river by river, state by state (in the United States at least), and fight by fight.

As long as water law is on the trailing edge of the water knife there is no reason to expect any better outcomes. Indeed, there is really no such thing as "water law." More accurately, it is a label that covers a smattering of state, federal, and tribal laws. It covers private and public rights and duties. It spills into admiralty and environmental law and has roots that run deep into common and civil law traditions.

4. Examples of programs facing such issues and challenges include the state and federal programs to restore ecologic sustainability to the Everglades, Coastal Louisiana, and the San Francisco Bay Delta. See U.S. Commission on OCEan Policy, AN OCEan BLUEPRINT FOR THE 21ST CENTURY 172-75 (2004), archived at http://perma.cc/TA9G-6ZYD. 
Where its roots do not run is into hydrology, climatology, ecology, economic efficiency, and social justice - the very fields that increasingly demark the boundaries of water management-and conflict.

Plainly, something has to change. We can either hope that somehow, sovereign states, people, climates, and ecosystems will adapt themselves to the architecture of current law, or we can begin to reshape our water laws and policies to reflect the realities of water systems and fundamental human and ecologic needs. It will not be easy, but we must act now if society wishes to truly manage water rather than be managed by the effects of shortages or sudden floods.

\section{Point OF DEPARTURE—CURRENT WATER LAW IN THE UNITEd STATES}

Water law in the United States deals mainly with who may use surface water or ground water, and for what purpose. Whether cast under the banner of riparian rights, prior appropriation, the rule of capture, or correlative rights, traditional water law is not so much about water as it is about the use and development of land. ${ }^{5}$ Developed in fits and starts and on a state-by-state basis, water law traditionally had little or no grounding in hydrological or ecological concepts. At a time when populations were smaller, technology was more limited, and our understanding of the broader values of water was less developed, it may not have mattered. Today it does. Water conflicts that were once primarily local are increasingly regional and international. ${ }^{6}$ Conflicts that were once entirely focused on competing land uses now include environmental and cultural dimensions. Conflicts over what were once perceived to be presumptively unlimited, static water resources are now being shaped by fundamental uncertainties about stream flows and aquifer sustainability. ${ }^{7}$ And water resources that were long believed to be solely the subject of state laws are now also seen

5. It is beyond the scope of this Article to explain the history and nature of these doctrines. Readers interested in learning more about them can consult any number of treatises and case books. See, e.g., ROBERT BECK ET AL., WATERS AND WATER RIGHTS (3d ed. 2012); ROBERT ABRAMS ET AL., LEGAL CONTROL OF WATER RESOURCES (5th ed. 2012).

6. See, e.g., Tarrant, 133 S.Ct. 2120 (dealing with the waters in the Red River watershed which were the subject of a multistate compact between Texas, Oklahoma, Arkansas, and Louisiana). Another example is the long standing dispute between Alabama, Florida, and Georgia over the Apalachicola, Chattahoochee, and Flint Rivers. See David Alderstein, Governor: Florida Will Sue Georgia Over Water, THE News HERALD, http://www.newsherald.com/news/government/governor-florida-will-sue-georgia-over-water -1.186138 (Aug. 13, 2013, archived at http://perma.cc/3J5L-3BNU).

7. See Tarrant, 133 S.Ct. 2120; see also U.S. DEPT. OF THE INTERIOR, BUREAU OF Reclamation, Reclamation: Managing Water in the West-Colorado River Basin SUPPLY AND DEMAND STUDY (2012), archived at http://perma.cc/LL6Y-8FYJ (noting the growing uncertainty over Colorado River management driven by significant reductions in flows and precipitation). 
as articles of commerce subject to the Commerce Clause of the US Constitution, ${ }^{8}$ or are being managed via multi-state compacts pursuant to the Compact Clause $^{9}$ of the Constitution or federal water project authorizations.

\section{THE BOUNDARIES OF WATER STEWARDSHIP}

Managing water is no simple matter because there is nothing else like it on earth or in our legal traditions. Water is essential to life and commerce. It can simultaneously be a commodity and void of ownership. It can determine the value of property rights while not being property itself. It is culturally venerated and feared. It links and separates and for many purposes has no substitutes. As noted earlier, when there were fewer of us and our freshwater resources were more abundant, we could get away with approaches to managing water that were narrowly focused, myopic, and aimed at showing water who was boss. Whatever justification may have existed to justify that approach, it is fading fast. ${ }^{10}$

The importance of water to each of us is of course obvious and nothing new. But the world we live in is increasingly dominated by agencies and institutions that pursue narrow objectives and is a place where water is more an instrumentality to be exploited or a bother to be eliminated. Being creatures of law and politics, these entities often exist apart from our communities, values, and aspirations. Accountable to their missions, members, or shareholders, these increasingly global organizations have made possible the development and exploitation of water resources on a scale unknown in our history. ${ }^{11}$ They are exquisitely good at what they do, but not nearly as good at learning things that are not central to growing their businesses. Sustainability and comprehensive management are rarely their business.

Even when water presents barriers to growth, it is almost invariably

8. See Sporhase v Neb., 458 U.S. 941 (1982).

9. U.S. CONST. art. I, $\S 10, \mathrm{cl} .3$.

10. See William Sarni, Corporate Water Strategies, 3-4 (2011) (noting the shift from managing water as a largely limitless resource to one driven by sustainability concerns).

11. An example in the international arena is the North American Free Trade Agreement (NAFTA) which has spawned concerns that bulk water transfers to the United States could be required by the Treaty, particularly via the Security and Prosperity Partnership created in 2005 that some have criticized as being dominated by business interests. See Steven Leahy, Canada Losing Water Through NAFTA, INTER PRESS SERvice (Sept. 23, 2007), http://www.ipsnews.net/2007/09/canada-losing-water-through-nafta/ (archived at http://perma.cc/N57S-P5DX). A more recent analysis has concluded that those fears are not without some basis, noting that Canada is not currently obligated to export water in bulk under NAFTA. See VICTORIA COFFIN ET AL., OUR WATER AND NAFTA 1 (2011), archived at http://perma.cc/H4LQ-Y93D. 
met by "can do" commitments to find more water, somewhere, somehow. ${ }^{12}$ The increasingly certain fact that there is not enough freshwater available for all the people and uses in all the places we have chosen (or been forced) to settle has not been seen as cause for thoughtful comprehensive planning and management, at least not on a scale commensurate with the problem. On the contrary we are witnessing a growing scramble for water, a competition that pits those without water against those with it, those with wealth and power against those without it, and those who see water as a commodity against those who see it primarily as a sustainer of nature, culture, and communities. Increasingly, this competition is pushing us to new tensions and conflicts along water's four boundaries.

\section{THE FOUR BOUNDARIES OF WATER}

Earlier I listed eleven factors that need to be considered when defining the boundaries of water stewardship. To give them a perhaps more useful context, they can be broken into four general boundary categories.

\section{A. Political and Legal Boundaries-Sovereign Boundaries (National, State, Local, Tribal) ${ }^{13}$}

The lines and names we put on maps tell us much about water management. They tell us where national, state, and local boundaries lie, and where sovereign powers reside, at least in part. But they are only manifestations of the actual boundaries, which are creatures of law and the political and legal systems that create and maintain them. These are the boundaries most commonly thought of when the term "transboundary" is used. From nation to nation, nation to state, state to state, tribe to state, sovereign to property owner, and property owner to property owner, the boundaries between the rights and obligations of various actors mark the friction zones that sometimes flare into legal or intergovernmental conflicts. In 2012 alone, the Pacific Institute documented thirty-one "water conflicts" around the world. ${ }^{14}$

These boundaries do more than mark the bounds of sovereignty. They also mark the boundaries of legal systems that define rights and duties with

12. See, e.g., Nate Blakeslee, Drawing Straws, TEXas MONTHLY, $\mathrm{http} / / /$ trinitywaters.org/press-room/drawing-straws/ (July 1, 2012, archived at http://perma.cc/5C5X-DDXU).

13. A good sampling of the scale of political transboundary water disputes and the issues they present can be found in the proceedings of such events as World Water Week in

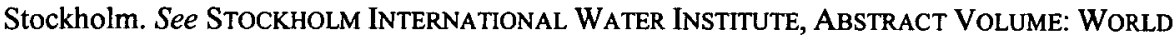
WATER WEEK IN STOCKHOLM 12 (2006) archived at http://perma.cc/3SR-VF9W.

14. Water Conflict Chronology List, PACIFIC INSTITUTE, http://www.worldwater.org/conflict/list/ (last visited Dec. 20, 2013, archived at http://perma.cc/528F-5CH3). 
respect to water. These legal systems define waters and water rights in terms that distinguish between surface and subsurface water, lakes and flowing water, water that is navigable and nonnavigable, water that is capable of ownership or not, and so on. A single river or lake can be defined and regulated in a host of different and conflicting ways depending on the jurisdictions it touches. By way of illustration, any truly comprehensive attempt to manage the waters of the Mississippi River would have to include two nations, two Canadian provinces, thirty one states, and a variety of tribes, each with its own set of laws, policies, and priorities which themselves can be dizzyingly balkanized. As messy as boundary disputes of this sort can be, they are the types we are most accustomed to dealing with through diplomacy, legal action, legislation, or, in extreme cases, saber rattling.

\section{B. Physical Boundaries-Geologic, Geographic, Hydrologic and Ecologic}

Sir Francis Bacon famously noted that, "[n]ature to be commanded must be obeyed," knew nothing about the future of water law. In nature, water works with plants, rocks, soils, and geophysics to build dynamic landscapes and water sheds. We can name, use, and alter water but it ultimately does not take well to being tamed. ${ }^{16}$ Yet still we persist in ignoring or defying the physical aspects of water, failing to recognize that the banks of rivers do not define rivers, but flood plains and watersheds define them-and they change. We continue to argue over the legal definitions of navigable waters and water of the United States as if writing a wetland, stream, lake, bog, or aquifer out of our legal landscape takes them out of the physical one in which we actually live. ${ }^{17}$ The failure to see and respect these boundaries has bitten us time and again, from Johnstown to the great Mississippi River flood of 1927, from the great Dust Bowl to the current spreading collapse of the High Plains Aquifer, ${ }^{18}$ and from Hurricane Katrina to Hurricane Sandy,

15. SIR Francis BACON, Novum ORganum 157 (1620), archived at http://perma.cc/4S4W-N8F4 (alteration added).

16. Mark Twain more colorfully made this point in Life on the Mississippi, commenting that "[t]en thousand River Commissions, with the mines of the world at their back, cannot tame that lawless stream ...." MARK TWAIN, LiFE ON THE MISSISSIPPI, ch. XXVIII (1896), archived at http://perma.cc/ZE4Y-FX7Q.

17. See, e.g., Raponos v. United States, 547 U.S. 715 (2006); see also H.R. 1330, 104th Cong. (1995), archived at http://perma.cc/6VBV-P3EN (outlining the Comprehensive Wetlands Conservation and Management Act, introduced March 12, 1991 (not enacted) to legislatively define and categorize wetlands).

18. See, e.g., LEONARD F. KonIKOW, GROUNDWATER DEPLETION IN THE UNITED STATES (1900 - 2008): U.S. GEOLOGICAL SURVEY SCIENTIFIC INVESTIGATIONS REPORT 2013-5079 (2013), archived at http://perma.cc/8WWL-BJJA; see also Suzanne Goldenberg, A Texan Tragedy: Ample Oil, No Water, THE GuARDIAN, 
which alerted us to the fact that New York City and New Orleans are both below sea level cities, albeit in different ways. John Wesley Powell's warning after the Johnstown Flood holds even truer today: "Modern industries are handling the forces of nature on a stupendous scale.... Woe to the people who trust these powers to the hands of fools! Then wealth is destroyed, homes are overwhelmed, and loved ones killed."19

Where Powell was looking at an industrializing country, we are in a different place today, one that has moved well beyond the scale of human activity he could foresee. To be fair, we have learned and applied some important lessons along the way. But it is only a matter of degree. Where he was concerned with the risks posed by localized projects, (which is still a concer $^{20}$ ) we are now facing systemic water challenges. We have built cities in places with no rivers and finite ground water, and still expect them to grow. We have crowded our coasts and now face rising seas and threats to drinking water supplies.

These risks and challenges will not go away even if we commune perfectly with nature. To live is to live at risk. But by more fully acknowledging the comprehensive and dynamic nature of the physical aspects of our water environment and the borders between it and us, we can more honestly assess and live with the risk. There is evidence that that is beginning to happen. Prior to Hurricane Katrina, the U.S. Army Corps of Engineers built flood protection levees; today they build flood risk reduction systems. ${ }^{21}$ It is a start.

\section{Cultural and Economic Boundaries-Social, Economic, Professional}

Our relationships with water may play out through legal structures and be ultimately defined by water's physical boundaries, but at its heart, our relationships with water are shaped by cultural and economic forces. The reason is straightforward: we do not manage things without a reason. There are reasons we live near water, celebrate water, pollute water, and

http://www.theguardian.com/environment/2013/aug/11/texas-tragedy-ample-oil-no-water (Aug. 11, 2013, archived at http://perma.cc/4ES6-W53G).

19. John Wesley Powell, The Lesson of Conemaugh, 149 THE NORTH AMERICAN REVIEW 150, 156 (1889), archived at http://perma.cc/8SQ6-U6SR.

20. The ongoing vulnerability of the levees on the Sacramento River, Jacques Descloitres, Flooding After Levee Break in San Joaquin-Sacramento River Delta, California (False Color), Visible Earth, http://visibleearth.nasa.gov/view.php?id=71323, (Dec. 26, 2013, archived at http://perma.cc/6YH3-NX2K), and around Florida's Lake Okeechobee, Michael Watkins, 3 Troubling Lake Okeechobee Levee Facts, Hurricane Analytics, http://www.hurricaneanalytics.com/2013/02/three_levee_fact/, (Feb. 26, 2013, archived at http://perma.cc/K9XC-3SDH), are prime examples of this.

21. See generally Mark Schleifstein, Upgraded Metro New Orleans Levees Will Greatly Reduce Flooding, Even in 500-year Storms, NOLA.COM, http://www.nola.com/hurricane/ index.ssf/2013/08/upgrated_metro_new_orleans_lev.html (Aug. 16, 2013, archived at http://perma.cc/EQ3-E458). 
write laws to govern water use. There are also reasons why water is relatively more abundant and clean where there is wealth or stringent laws to protect water resources. Those reasons are found in our cultural and economic values and priorities. Because water is both a biologic and an economic necessity, it poses stewardship challenges unlike those of any other substance on earth. This has given water a unique place in our cultures, economies, and laws; a place shot through with difficult, if not irreconcilable, public policies that have made water the non-commodity commodity.

The space between water as something with a price and something priceless marks a boundary that is one of the most difficult concepts confronting water managers. On the one hand, there are compelling arguments to be made for sending water to wherever there is sufficient demand to pay for it. On the other hand, there are arguments rooted in nationalism, social justice, environmental stewardship, cultural identity, and spiritual well-being that are just as compelling and often more deeply ingrained than market forces.

Those are hard nuts to crack, and it does not help that modern society increasingly opts to entrust the nut cracking to various professionals by charging them to develop comprehensive plans, watershed commissions, multistate compacts, and international treaties. This is not a criticism of that approach, but rather a recognition of the fact that those professions bring their own cultures and professional boundaries with them. Asking an engineer to manage water for ecologic purposes is a tall order. Asking a lawyer to design cost-effective water infrastructure is trouble in the making. Asking an ecologist or biologist to explain the legal landscape of rights, duties, and jurisdictions is a reach. These professionals are all important, but they usually play discrete roles and serve disparate interests. The boundaries between professions and professionals can be managed, but not if they are unacknowledged.

How any particular water dispute will be resolved is hard to say. What is not hard to predict is that water conflicts are increasingly not going to be resolved purely on utilitarian or economic terms. The moral dimension of water is taking on greater importance. The utilitarianism of those such as William Muholland ${ }^{22}$ is now weighed against the absolute truth that water is a human right ${ }^{23}$ and is balanced against the needs of the

22. Mulholland was quoted as calling for a dam across the Yosemite River that would flood much of Yosemite National Park in order to, "stop the goddamn waste." MaRC Reisner, Cadillac Desert 92 (revised ed., Penguin Books 1993).

23. This was perhaps most directly articulated by then United Nations Secretary Kofi Annan, who said that "[a]ccess to safe water is a fundamental human need, and, therefore, is a basic human right." See Press Release, United Nations, Access to Safe Water Fundamental Human Need, Basic Human Right. 
environment. In some ways we may be witnessing the emergence of a "land (and water)" ethic as called for by Aldo Leopold in his 1949 classic, $A$ Sand County Almanac. ${ }^{24}$

\section{Knowledge Boundaries}

Almost everything we have ever done in the realm of water management is a function of two things: what we knew (or thought we knew), about water at some point in time, and the presumptions we employed when faced with uncertainty. The boundaries between knowledge, belief, and ignorance are as fundamental as national boundaries where water stewardship is concerned. Regardless of what legal regime a state or nation employs-riparianism, prior appropriation, the rule of capture, or another-it is rooted in a sense of what was known or believed about water at some point. Knowledge, like water, is dynamic and ever changing.

The same is not true of the laws, property rights, programs, and infrastructure that we have created to handle the myriad aspects of water. The Colorado Compact is based on a water budget that turns out to be off by more than 1.5 million acre feet per year. ${ }^{25}$ Hurricane protection flood walls built around New Orleans to withstand the "most severe meteorological conditions reasonably characteristic in the region," on 1950 s hurricane science, ${ }^{27}$ were shredded by Hurricane Katrina, a storm we had already come to know was not uncharacteristically severe. The effects of climate change and sea level rise currently are challenging our previous knowledge about water and our relations with it. So far, very few rights, duties, laws, or projects have changed to reflect this increasing

23. Says Secretary-General in Message on World Water Day, U.N. Press Release SG/SM/7738 (Mar. 22, 2001, archived at http://perma.cc/TCW3-GTJ8) (alteration added). The legal architecture for framing that right is still emerging, but more information about it can be found through a number of sources, including the Rights to Water and Sanitation website. THE RIGHTS TO WATER AND SANITATION, http://www.righttowater.info/ (last visited Dec. 22, 2013, archived at $\mathrm{http}: / /$ perma.cc/M8VX-GJGD).

24. See Aldo Leopold, A SAND CounTy Almanac 167 (1989).

25. The Colorado River Compact of 1922 which allocated 15 million acre feet per year between the four-state upper basin and the three-state lower basin between the seven basinstates was based on an estimated annual flow of over 16.4 million acre feet per year. In reality, the rate of flow has been closer to 14.3 million acre feet per year. See BARTON H. ThOMPSON, JR. ET AL., Legal CONTROL OF WATER Resources 985 (5th ed. 2012) (citing Connie A. Woodhouse, Stephen T. Gray \& David T. Meko, Updated Streamflow Reconstructions for the Upper Colorado River Basin, 42 Water Resources Research WO5415 (2006)).

26. See Christine F. Andersen et. al., Am. Soc'y of Civil Eng'rs, The New Orleans Hurricane Protection System: What Went Wrong and Why 20 (2007), archived at http://perma.cc/E5LN-VNG6.

27. Id. 
knowledge. $^{28}$

Since knowledge is rarely perfect and more infrequently stays perfect, the presumptions that guide our actions in the case of uncertainty or ignorance assume positions of extreme importance. In the history of American water resource management, the trend has been to allow greater water use until and unless it produces demonstrable harm. Whether couched in terms of "reasonable use," "waste," "beneficial use," or the "rule of capture," we have pursued a course of action that favors the use and exploitation of water resources to encourage economic and geographic growth. The results have been spectacular when viewed through the lens of those goals and a century time-scale. But those benefits are permanent and often have come at a cost borne by the environment or later generations.

Presumptions that unutilized water is wasted and that our growth and prosperity can transcend environmental constraints may be problematic, but are not ubiquitous. Countervailing pressures from land use laws, environmental laws, and background legal principles, such as the public trust doctrine, can override, and sometimes have overridden, the utilitarian tendencies of traditional water law. But the presumption that things will somehow work out and that there is enough time for relatively painless adaptation is pervasive and increasingly doubtful. Time and options are already running short for a growing number of communities. We may find comfort in our beliefs, level of knowledge, and presumptions, but when they become a boundary against reality, our sustainability comes starkly into question.

\section{CONCLUSION}

Water management is the art of balancing uses against availability. In the absence of competing demands or limited availability, the issue of management never really arises. The converse is also true, as the greater the competition and the more scarce the resource, the greater the need for management. And the type of management that is increasingly needed is conflict resolution, as opposed to the more traditional ministerial tasks of delivering water and processing wastewater.

28. One exception is the hurricane protection system around New Orleans. Following Hurricane Katrina, Congress charged the Army Corps of Engineers to upgrade the system to the point it could withstand a once-in-100-year storm event. See New Orleans District, ARMY CORPS OF ENGINEERS, http://www.mvn.usace.army.mil/Missions/HSDRRS/ RiskReductionPlan.aspx (last visited Oct. 7, 2013, archived at http://perma.cc/5WZDS7L3); 100 Year Level Protection, ARMY CORPS OF ENGINEERS, http://www.mvn.usace. army.mil/Missions/HSDRRS/RiskReductionPlan/100YearLevelProtection.aspx (last visited Oct. 7, 2013, archived at http://perma.cc/D8CP-5K4J). This more robust system actually offers a lower amount of protection, moving from the most severe storm event to the decidedly lower one-in-100-year standard. See generally 100 Year Level Protection, supra. 
Transboundary conflicts over water between nations and states are nothing new. What is new is the frequency and seriousness of these conflicts and their increasingly complex and compelling array of geographic, ecologic, cultural, informational, and legal factors that present their own boundaries. A fight about water is almost always about much more than water. Culture, pride, strategic or personal advantage, tradition, morality, the limits of our knowledge, and the firmness of our beliefs are assuming dimensions of importance that we have not seen before. Try as we might to teach, practice, or manage through something called "water law" as though it is a distinct body of law, we will fail because it is not. Indeed, water conflicts are increasingly less about law than about equity, "human rights," and power.

There is no road map through these trans-boundary thickets, but there are reasons for hope. First, because of necessity we are getting better at understanding the comprehensive nature of water and working with it on larger scales. Second, there is an inevitable aspect of water that sooner or later focuses our attention on the realities of both its values and risks. Benjamin Franklin's observation that "[w]hen the [w]ell's dry, we know the $[w]$ orth of [w]ater," ${ }^{29}$ holds true today; only today, we have a lot more riding on those wells.

Finally, the growing recognition that access to water is a fundamental human right, and that human society is not divorced from nature is beginning to forge a new foundation for water management-a land and water ethic, an ethic that can serve as a bridge across the many boundaries challenging water managers and advocates today. Leopold may yet have his day.

29. BENJAMIN FrankLIN, PoOR RichaRd's AlmanaC (1746) (alterations added). 
